Original

\title{
T-2 Toxin-Induced Apoptosis and $c$-fos mRNA Expression in Con A-Stimulated Mouse Thymocyte Primary Cultures
}

\author{
Junko Shinozuka ${ }^{1}$, Hodaka Suzuki ${ }^{1}$, Shigeki Tsutsui ${ }^{1}$, Hiroyuki Nakayama ${ }^{1}$, and \\ Kunio Doi ${ }^{1}$ \\ ${ }^{1}$ Department of Veterinary Pathology, Graduate School of Agricultural and Life Sciences, The University of Tokyo, \\ 1-1-1 Yayoi, Bunkyo-ku, Tokyo 113-8657, Japan
}

\begin{abstract}
The development of apoptosis and the expression of $c$-fos mRNA were investigated up to 24 hours after treatment (HAT) with $0.2 \mathrm{~g} / \mathrm{ml}$ of T-2 toxin in Con A-stimulated primary thymocyte cultures prepared from BALB/c mice. Cell viability began to decrease from 1 to $3 \mathrm{HAT}$, and it was approximately 50\% at $6 \mathrm{HAT}$. The level of cytoplasmic nucleosomes peaked at 3 HAT (about 2 times of control) and decreased thereafter. At 6 HAT, thymocytes showed irregular-shaped or fragmented nuclei. By RT-PCR, the level of $c$-fos mRNA began to increase within 1 HAT, and maintained a high level through the observation period. Preincubation with BAPTA/AM, a intracellular calcium ion chelator, markedly suppressed the expression of $c-f o s$ mRNA and the level of DNA fragmentation induced by T-2 toxin. Although less effective, preincubation with $\mathrm{H}-7$, a protein kinase $\mathrm{C}$ (PKC) inhibitor, also depressed the above-mentioned two parameters. These findings indicate that, in mouse thymocyte primary cultures treated with T-2 toxin, $c-f o s$ may play an important role in the induction of apoptosis and the increase in intracellular calcium ion may be closely related with the expression of $c$-fos mRNA. In addition, these findings also suggest that PKC-dependent pathway may be involved in T-2 toxin-induced thymocyte apoptosis. (J Toxicol Pathol 2001; 14: 247-251)
\end{abstract}

Key words: T-2 toxin, apoptosis, primary thymocyte culture, $c$-fos, Calcium iron, PKC

\section{Introduction}

$\mathrm{T}-2$ toxin is a kind of trichothecene mycotoxin produced by species of the genus Fusarium. It infects corns, wheat, barley and rice crops in the field or during storage ${ }^{1}$ and affects human and farm animals. Oral, parenteral and cutaneous exposures of trichothecene mycotoxin produce lesions in hematopoietic, lymphoid and gastrointestinal tissues as well as functional suppression in reproductive organs ${ }^{2-5}$. Our reseach group first clarified that T-2 toxininduced death of lymphocytes in the thymus ${ }^{6,7}$, splenic white pulp $^{6,7}$ and Peyer's patches ${ }^{8}$ is apoptosis. After that, our research group also confirmed that hematopoietic cells in the bone marrow and splenic red pulp ${ }^{9}$, and intestinal crypt epithelial cells ${ }^{10}$ die through apoptosis following T-2 toxininoculation.

In the study on the sequential changes in mRNA expression of apoptosis-related genes (fas, p53, bcl-2, c-myc and $c-f o s)$ in the thymus of mice treated with T-2 toxin,

Received: 10 May 2001, Accepted: 17 July 2001

Mailing address: Kunio Doi, Department of Veterinary Pathology, Graduate School of Agricultural and Life Sciences, The University of Tokyo, 1-1-1 Yayoi, Bunkyo-ku, Tokyo 113-8657, Japan TEL/FAX: 81-3-5841-8185

E-mail: akunio@mail.ecc.u-tokyo.ac.jp
Shinozuka et al. ${ }^{11}$ reported that $c$-fos mRNA expression significantly increased prior to the development of apoptotic cell death. Recent studies also reported that the expression of $c$-fos mRNA precedes the initiation of apoptosis or it is concomitant with apoptosis in many systems ${ }^{12-16}$. In addition, the regulatory mechanisms underlying transcription of the $c$-fos have been extensively studied, and it is well established that both mobilization of intracellular ionized calcium $\left(\left[\mathrm{Ca}^{2+}\right]_{\mathrm{i}}\right)$ and activation of protein kinase $\mathrm{C}$ (PKC) lead to an accumulation of this transcript ${ }^{17-19}$.

The purpose of this study was to clarify the relationship between the development of apoptosis and the expression of $c$-fos mRNA and to examine the effects of calcium ion chelators and a protein kinase $\mathrm{C}$ (PKC) inhibitor on the expression of $c$-fos mRNA and the DNA fragmentation in T2 toxin-treated mouse thymocytes.

The present study was approved by The Laboratory Animal Use and Care Committee of Graduate School of Agricultural and Life Sciences, The University of Tokyo.

\section{Materials and Methods}

Animals

Four-week-old male BALB/c mice were purchased from SLC (Shizuoka, Japan) and acclimatized for 1 week. They were kept under controlled conditions (temperature, 23 
$\pm 2{ }^{\circ} \mathrm{C}$; relative humidity, $55 \pm 5 \%, 14-16$ air changes per hour and a 14-hr light and 10-hr dark cycle) in an animal room and fed commercial pelleted chow (MF, Oriental Yeast Co., Ltd., Tokyo, Japan) and water ad libitum.

\section{Cell cultures}

The thymus was obtained from 5 -week-old male BALB/c mice. Cells were suspended in Hank's buffered salt solution (HBSS) (Nissui Pharmaceutical Co., Tokyo, Japan) with $2 \%$ fetal bovine serum (FBS) (Lot. No. 6A4002, JRH Biosciences, Australia) and cultivated in RPMI-1640 medium (Nissui Pharmaceutical Co., Tokyo, Japan) supplemented with 10\% FBS, $2 \mathrm{mM}$ L-gultamine, $50 \mu \mathrm{M} 2-$ mercaptoethanol (ME) (WAKO Pure Chemical Co., Osaka, Japan $)$, penicillin $(100 \mathrm{U} / \mathrm{ml})$ and streptomycin $(100 \mu \mathrm{g} / \mathrm{ml})$ at $37^{\circ} \mathrm{C}$ in $5 \% \mathrm{CO}_{2}$ in air. For mitogen-induced blastogenesis, $5 \mu \mathrm{g} / \mathrm{ml}$ of Con A (WAKO Pure Chemical, Co., Osaka, Japan) was added to cultures and incubated at $37^{\circ} \mathrm{C}$ in $5 \% \mathrm{CO}_{2}$ in air for 48 hours.

\section{Treatment with T-2 toxin}

The stock solution of T-2 toxin (Lot. No. 117F4078, Sigma Chemical Co., St. Louis, USA) was dissolved in $99.5 \%$ ethanol, sterilized by filtration, and diluted to the final concentration of $0.2 \%$ in RPMI-1640 medium. Cells were incubated in the above-mentioned medium with T-2 toxin or solvent alone.

\section{Experimental designs}

Two experiments were carried out. In Experiment 1, the development of apoptosis and the expression of $c$-fos mRNA following T-2 toxin-treatment were investigated in Con A-stimulated mouse thymocyte primary cultures. In Experiment 2, the effects of chelation of calcium ion and inhibition of PKC activity on the development of T-2 toxininduced apoptosis were investigated in the same culture system.

Experiment 1: Cells $\left(4 \times 10^{6}\right.$ cells $\left./ \mathrm{ml}\right)$ were cultured in RPMI-1640 (supplemented as described above) in $36 \mathrm{~mm}$ dishes (SUMILON, Sumitomo bakelite Co., Tokyo, Japan). Then, $0.2 \mu \mathrm{g} / \mathrm{ml}$ of T-2 toxin or solvent alone were added to cultures and incubated at $37^{\circ} \mathrm{C}$ in $5 \% \mathrm{CO}_{2}$. At $1,3,6,12$ and 24 hours after treatment (HAT), cell viabilty was estimated by trypan blue exclusion method, and cell samples were obtained for reverse transcription-polymerase chain reaction (RT-PCR) and DNA fragmentation assays.

Experiment 2: $0.1 \mu \mathrm{g}$ of ethylene glycol-bis (baminoethyl-ether)-N, N, N', N'-tetraacetic acid (EGTA)(DOJINDO Chemical Lab., Kumamoto, Japan) was used as an extracellular ionized calcium $\left(\left[\mathrm{Ca}^{2+}\right]_{\mathrm{e}}\right)$ chelator, and $25 \mu \mathrm{M}$ of bis-(o-aminophenoxy)-ethane-N, N, N', N'tetraacetic acid tetrakis (BAPTA/AM) (DOJINDO Chemical Lab., Kumamoto, Japan) as an intracellular ionized calcium $\left(\left[\mathrm{Ca}^{2+}\right]_{\mathrm{i}}\right)$ chelator. As a protein kinase $\mathrm{C}$ (PKC) inhibitor, 20 $\mu \mathrm{M}$ of 1-(5-isoquinolinylsulfonyl)-2-methylpiperazine dihydrochloride (H-7) (Seikagaku Co., Tokyo, Japan) was used. Calcium chelators and a PKC inhibitor were dissolved in water or dimethyl sulfoxide (DMSO) (WAKO Pure Chemical, Co., Osaka, Japan) and diluted to the appropriate final concentration in RPMI 1640 medium.

Con A-stimulated mouse thymocytes which were preincubated with calcium chelators or a PKC inhibitor at the above-mentioned concentrations for 1 hour were treated with $0.2 \mu \mathrm{g} / \mathrm{ml}$ of $\mathrm{T}-2$ toxin at $37^{\circ} \mathrm{C}$ in $5 \% \mathrm{CO}_{2}$ in air for 3 hours. At 1 and $3 \mathrm{HAT}$, cell numbers were counted, and cell samples were obtained for RT-PCR and DNA fragmentation assays.

\section{$R N A$ extraction and $R T-P C R$ method}

In Experiment 1 and 2, total RNA extraction and RT reaction were carried out as described in the previous paper ${ }^{11}$, using Isogen (Nippongene Co., Ltd., Toyama, Japan) and SUPERSCRIPT preamplification system (GibcoBRL, Life technology Co., USA). Polymerase chain reaction (PCR) was performed with pairs of oligonucleotide primers corresponding to the cDNA sequences of mouse $c$-fos mRNA (sense: GAATGGTGAAGAC CGTGTCAGG; antisense: CGTTGCTGATGCTC TTGACTGG) and mouse glyceraldehyde-3-phosphate dehydrogenase (GAPDH) (sense: TGAAGGTC GGTGTGAACGGATTTGGC; antisense: CATGTAGGCCATGAGGTCCAC CAC). PCR was carried out in a $50 \mu \mathrm{l}$ reaction mixture containing $50 \mathrm{pM}$ of sense and antisense primer, 1.25 U AmpliTaq Gold ${ }^{\mathrm{TM}}, 10$ $\times$ PCR buffer and dNTP mixture (Perkin Elmer, NJ., USA). This was immediately followed by pre-heating at $95^{\circ} \mathrm{C}$ for 9 min, denaturation at $94^{\circ} \mathrm{C}$ for $1 \mathrm{~min}$, annealing for $1 \mathrm{~min}$ and extension at $72^{\circ} \mathrm{C}$ for $1 \mathrm{~min}$ using Takara PCR Thermal Cycler MP (Takara, Ohtsu, Japan). PCR products were identified by electrophoresis on 1\% agarose gels (Nippon Gene Co, Ltd., Toyama, Japan) followed by ethidium bromide staining. Fluorescence image of gel was visualized

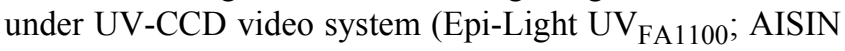
COSMOS R\&D Co., LTD., Tokyo) and the data were fed into a computer. The image was analyzed by using a Luminous Imager software (AISIN COSMOS R\&D Co., LTD., Tokyo). The $c$-fos mRNA level was shown as a relative ratio to GAPDH expression.

\section{Detection of DNA fragmentation by ELISA method}

DNA fragmentation in thymocytes was examined by ELISA method using a commercial kit (Cell Death Detection ELISA, Boehringer Mannheim GmbH, Germany). The nucleosomes of samples were incubated on anti-histonecoated microtiter plate module. After removal of unbound nucleosomes by washing step, anti-DNA-peroxidase (POD) reacted with the DNA-part of the nucleosome. After removal of unbound peroxidase conjugate by washing step, the amount of peroxidase retained in the immunocomplex was determined photometrically with $\operatorname{ABTS}$ (2, 2'-azino-di[3-ethylbenzthiazoline sulfonate]). From absorbance values at $405 \mathrm{~nm}$ using a microplate reader (Model 550, BIO-RAD, Tokyo, Japan), the specific enrichment of mono- and oligonucleosomes released into cytoplasm was calculated. 


\section{Statistical analysis}

The results of cell viability, and levels of $c$-fos mRNA expression and DNA fragmentation were expressed as mean \pm standard deviation (SD) of 3 or 4 dishes. Statistical analysis was done using the Student's and Welch's $t$-test.

\section{Results}

\section{Cell viability and DNA fragmentation assays}

The cell viability significantly decreased in ConAstimulated mouse thymocytes incubated with $0.2 \mu \mathrm{g} / \mathrm{ml}$ of T2 toxin. No effects on the cell viability and cytoplasmic nucleosomes were observed until 1 HAT. Thereafter, the cell viability began to decrease from 1 to $3 \mathrm{HAT}$, and it was approximately $50 \%$ at 3 HAT (Fig. 1 ). The level of cytoplasmic nucleosomes peaked at 3 HAT (about 2 times of control), and decreased thereafter (Fig. 1). At 6 HAT, thymocytes showed irregular-shaped or fragmented nuclei.

\section{Changes in c-fos mRNA expression after T-2 toxin- treatment}

Sequential changes of $c$-fos mRNA expression after T2 toxin-treatment are shown in Figs. 2 and 3. A rapid increase in $c$-fos mRNA expression was observed in Con Astimulated mouse thymocyte primary cultures after T-2 toxin-treatment. The level of $c-f o s$ mRNA began to increase within $1 \mathrm{HAT}$, and remained a high level through the observation period. In control cultures, the level of $c$-fos mRNA showed no significant changes through the observation period.

\section{Effects of calcium chelators and a protein kinase inhibitor}

The effects of calcium chelators and a PKC inhibitor on c-fos mRNA induction by T-2 toxin are shown in Figs. 4 and

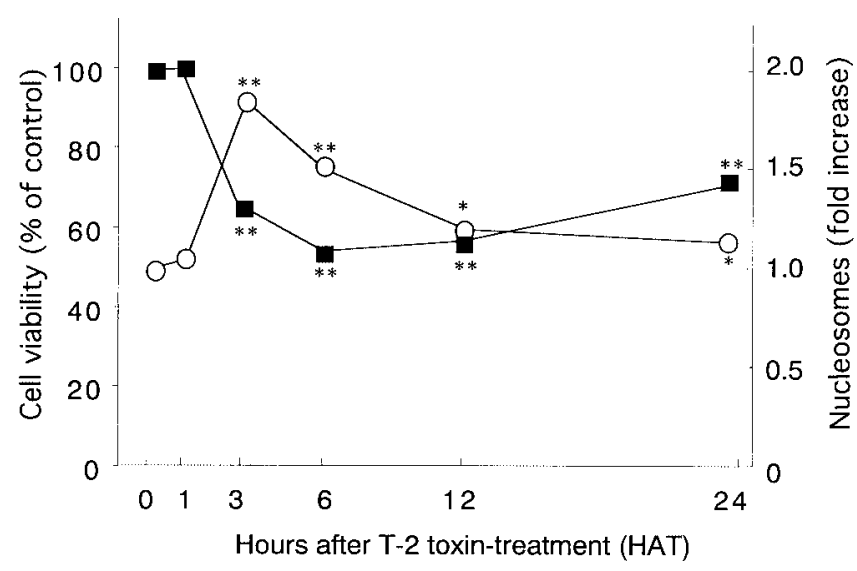

Fig. 1. Effect of $\mathrm{T}-2$ toxin on cell viability ( $\boldsymbol{\square})$ and DNA fragmentation $(\bigcirc)$. Con A-stimulated mouse thymocyte primay cultures were incubated with $0.2 \mu \mathrm{g} / \mathrm{ml}$ of T-2 toxin for up to 24 HAT. Each value represents the mean of 4 samples per groups. $*, p<0.05, * *, p<0.01$ : Significantly different from control.
5. Chelation of $\left[\mathrm{Ca}^{2+}\right]_{\mathrm{i}}$ by BAPTA/ AM resulted in a marked decrease of $c$-fos mRNA expression (one-fifth of T-2 toxin alone). On the other hand, chelation of $\left[\mathrm{Ca}^{2+}\right]_{e}$ by EGTA had no effect on $c$-fos mRNA expression. A PKC inhibitor, H-7, slightly depressed the expression of $c$-fos mRNA (two-third of T-2 toxin alone).

Fig. 6 shows the effects of calcium chelators and a PKC inhibitor on T-2 toxin-induced DNA fragmentation in mouse thymocyte primary cultures. BAPTA/AM and H-7 depressed the level of fragmented DNA to approximately $50 \%$ (BAPTA/AM) and $80 \%(\mathrm{H}-7)$ of T-2 toxin alone, respectively. However, EGTA showed no effect on the level of fragmented DNA.

\section{T-2 toxin}

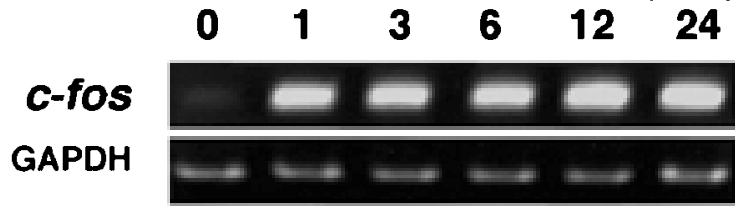

\section{Control}

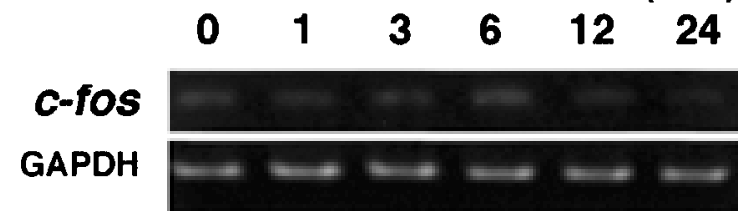

Fig. 2. Sequential changes of $c$-fos mRNA expression in Con A stimulated mouse thymocytes primary cultures which were incubated with $0.2 \mu \mathrm{g} / \mathrm{ml}$ of T-2 toxin or solvent alone (control) for up to 24 hours.

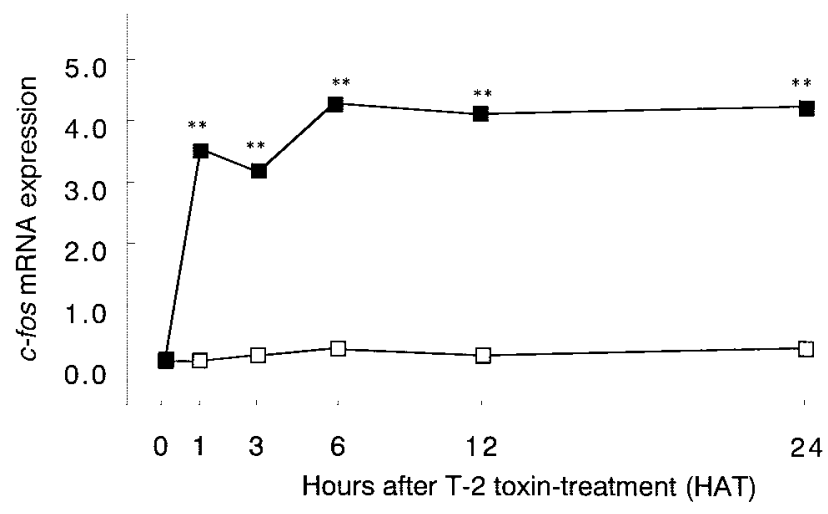

Fig. 3. Sequential changes of $c$-fos mRNA expression in Con Astimulated mouse thymocyte primary cultures were incubated with $0.2 \mu \mathrm{g} / \mathrm{ml} \mathrm{T}-2$ toxin ( $\boldsymbol{\square}$ ) or solvent alone ( $\square$ ) for up to 24 hours. Each value represents the mean of 4 samples per group. ${ }^{* *}, \mathrm{p}<0.01$ : Significantly different from control. 


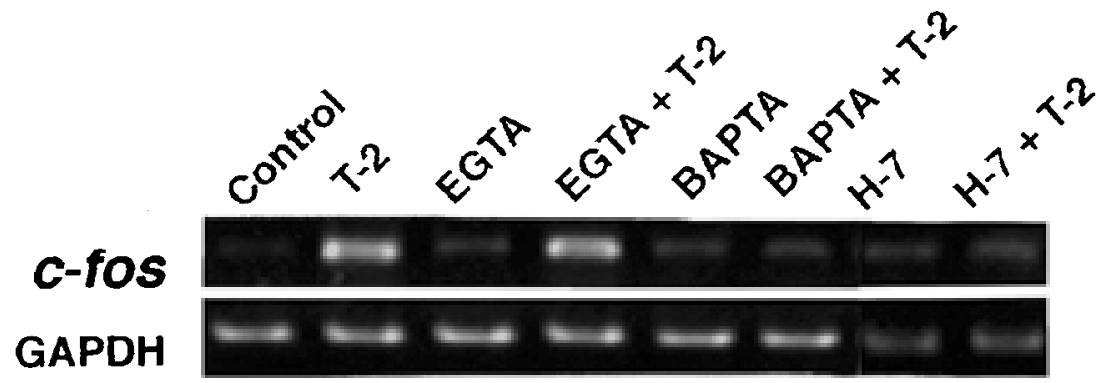

Fig. 4. Inhibition of T-2 toxin-induced $c$-fos mRNA by calcium chelators (EGTA and BAPTA/AM) and a PKC inhibitor (H-7) in Con A-stimulated mouse thymocyte primary cultures. Cells were preincubated in EGTA $(0.1 \mathrm{mM})$, BAPTA/AM $(25$ $\mu \mathrm{M})$ or $\mathrm{H}-7(20 \mu \mathrm{M})$, and then incubated with $0.2 \mu \mathrm{g} / \mathrm{ml}$ of T-2 toxin or solvent alone (control) for 1 hour.

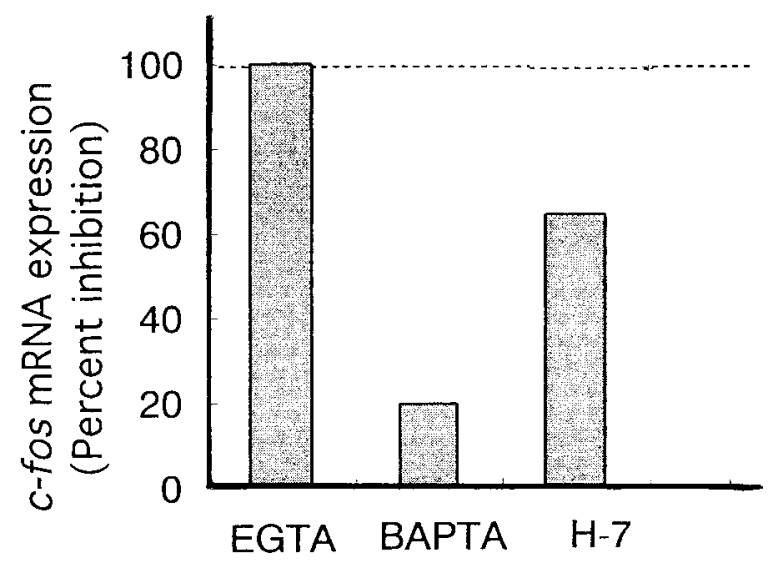

Fig. 5. Inhibition of $\mathrm{T}-2$ toxin-induced $c$-fos mRNA by calcium chelators and a PKC inhibitor in Con A-stimulated mouse thymocyte primary cultures. As to the conditions of cell cultures, see the footnote of Fig. 4. c-fos mRNA expression is expressed as the percent inhibition (percent of T-2 toxin alone). Each value represents the mean of 3 samples per group.

\section{Discussion}

The toxicity of T-2 toxin in Con A-stimulated mouse thymocytes was investigated. In the cells treated with 0.2 $\mu \mathrm{g} / \mathrm{ml}$ of $\mathrm{T}-2$ toxin, cell viability began to decrease from 1 to 3 HAT when the level of fragmented DNA began to increase. These findings suggest that T-2 toxin can also induce apoptotic cell death in mouse thymocytes in vitro as reported in in vivo study ${ }^{7}$. In addition, a rapid increase in $c$ fos mRNA expression was also observed prior to the development of T-2 toxin-induced apoptotic cell death in mouse thymocytes primary cultures as described in in vivo study $^{11}$.

To understand the mechanisms of T-2 toxin-induced thymocyte apoptosis, it is important to clarify the signal transduction pathway by which $c$-fos proto-oncogene is activated. There are substantial evidences that the expression of $c$-fos is reguated by the major intracellular second messenger, $\mathrm{Ca}^{2+18}$. In the present study, $c$-fos

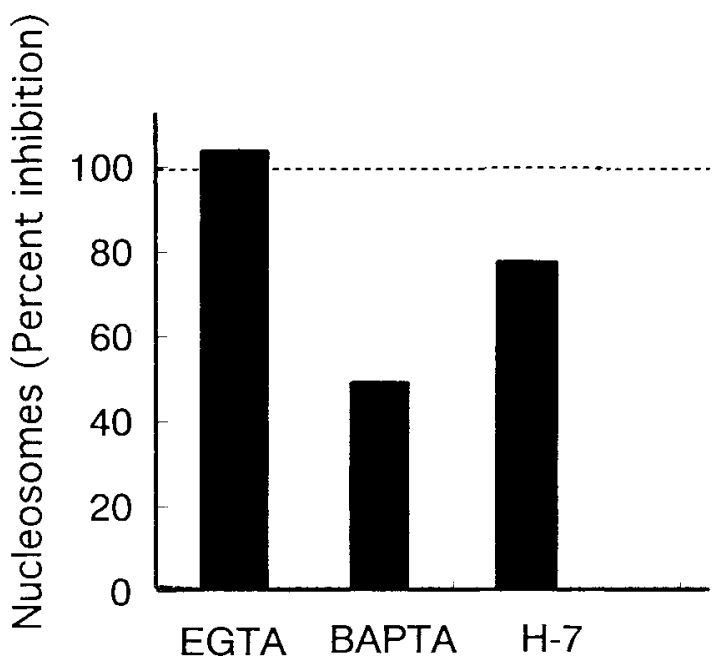

Fig. 6. Inhibition of $\mathrm{T}-2$ toxin-induced DNA fragmentation by calcium chelators and a PKC inhibitor in Con A-stimulated mouse thymocytes. Cells were preincubated with calcium chelators or PKC inhibitors, and then incubated with $0.2 \mu \mathrm{g} /$ $\mathrm{ml}$ of T-2 toxin for 3 hours. The level of DNA fragmentation is expressed as the percent inhibition (percent of T-2 toxin alone). Each value represents the mean of 3 samples per group.

induction was suppressed by chelation of $\left[\mathrm{Ca}^{2+}\right]_{\mathrm{i}}$, suggesting that T-2 toxin-induced $c$-fos expression depends on $\left[\mathrm{Ca}^{2+}\right]_{\mathrm{i}}$. Similar involvement of $\left[\mathrm{Ca}^{2+}\right]_{\mathrm{i}}$ has been reported in the induction of $c$-fos after oxidative stress ${ }^{20}$ and of hsp70 after heat shock ${ }^{21}$. Although the effect of T-2 toxin on $\left[\mathrm{Ca}^{2+}\right]_{\mathrm{i}}$ remains obscure, Yoshino et $a .^{22}$ reported that the level of $\left[\mathrm{Ca}^{2+}\right]_{\mathrm{i}}$ was markedly elevated in HL-60 cells after exposure to T-2 toxin. They also reported that intracellular calcium chelators inhibited apoptosis induced by T-2 toxin in HL-60 cells $^{22}$. In this study, BAPTA/ AM depressed the increase in the level of fragmented DNA induced by T-2 toxin. As mentioned above, the mechanism of mobilization of $\left[\mathrm{Ca}^{2+}\right]_{i}$ is still obscure. However, chelation of $\left[\mathrm{Ca}^{2+}\right]_{e}$ by EGTA had no effect on the expression of $c$-fos mRNA and the induction of DNA fragmentation in mouse thymocyte primary cultures 
following T-2 toxin-treatment, suggesting that the increase in $\left[\mathrm{Ca}^{2+}\right]_{\mathrm{i}}$ may be due not to the influx of extracellular $\mathrm{Ca}^{2+}$ but to the intracytoplasmic release of $\mathrm{Ca}^{2+}$ from endoplasmic reticula.

Although less effective as compared with BAPTA/AM, a chelator of $\left[\mathrm{Ca}^{2+}\right]_{i}, \mathrm{H}-7$, a PKC inhibitor, also showed depressive effects on T-2 toxin-induced c-fos mRNA expression and DNA fragmentation in mouse thymocyte primary cultures. This suggests that PKC-dependent pathway may be also involved in T-2 toxin-induced apoptosis.

In conclusion, in Con A-stimulated mouse thymocyte primary cultures, $c$-fos may play an important role in the induction of apoptosis, and $\left[\mathrm{Ca}^{2+}\right]_{\mathrm{i}}$ may be closely related with the expression of $c$-fos mRNA. PKC-dependent pathway may also be involved in T-2 toxin-induced thymocyte apoptosis.

\section{References}

1. Nelson PE, Dignani MC, and Anaissie EJ. Taxonomy, biology, and clinical aspects of Fusarium species. Clin Microbiol Rev 1994; 7: 479-504.

2. Stanford GK, Hood RD, and Hayes AW. Effect of prenatal administration of T-2 toxin to mice. Res Commun Chem Pathol Pharmacol 1975; 10: 743-746.

3. Williams PP. Effects of T-2 mycotoxin on gastrointestinal tissues: a review of in vivo and in vitro models. Arch Environ Toxicol 1989; 18: 374-387.

4. IARC. Evaluation of the Carcinogenic Risk of Chemicals. In: IARC Monographs on the Evaluation of the Carcinogenic Risk of Chemicals to Humans. Lyon, France, 467-488, 1993.

5. Sharman RP. Immunotoxicity of mycotoxins. J Dairy Sci 1993; 76: 892-897.

6. Shinozuka J, Uetsuka K, Nakayama H, and Doi K. T-2 toxin-induced apoptosis in lymphoid organs of mice. Exp Toxicol Pathol 1997; 49: 387-389.

7. Shinozuka J, Li GM, Uetsuka K, Nakayama H, and Doi K. Process of the development of T-2 toxin-induced apoptosis in lymphoid organs of mice. Exp Anim 1997; 46: 11171126.

8. Li GM, Shinozuka J, Uetsuka K, Nakayama H, and Doi K. T-2 toxin-induced apoptosis in Peyer's patches of mice. J Toxicol Pathol 1997; 10: 59-61.

9. Shinozuka J, Suzuki M, Noguchi N, Sugimoto T, Uetsuka K, Nakayama H, and Doi K. T-2 toxin-induced apoptosis in hematopoietic tissues of mice. Toxicol Pathol 1998; 26: 674-681.

10. Li GM, Shinozuka J, Uetsuka K, Nakayama H, and Doi K.
T-2 toxin-induced apoptosis in intestinal crypt epithelial cells in mice. Exp Toxicol Pathol 1997; 49: 447-450.

11. Shinozuka J, Tsutsui S, Ishigami N, Ueno-Yamanouchi A, Nakayama H, and Doi K. Development of apoptosis and changes in apoptosis-related genes expression in the mouse thymus following T-2 toxin-inoculation. J Toxicol Pathol 1999; 12: 77-81.

12. Colotta F, Polentarutti N, Sironi M, and Mantovani A. Expression and involvement of c-fos and c-jun protooncogenes in programmed cell death induced by growth factor deprivation in lymphoid cell lines. J Biol Chem 1992; 267: 18278-18283.

13. Smeyne RJ, Vendrell M, Hayward M, Baker SJ, Miao GG, Schilling K, Robertson LM, Curran T, and Morgan JI. Continuous c-fos expression precedes programmed cell death in vivo. Nature 1993; 363: 166-169.

14. Marti A, Jehn B, Costello E, Keon N, Ke G, Martin F, and Jaggi R. Protein kinase A and AP-1 (c-fos/JunD) are induced during apoptosis of mouse mammary epithelial cells. Oncogene 1994; 9: 1213-1223.

15. Hu L, Hatano M, Ruther U, and Tokuhisa T. Overexpression of c-fos induces apoptosis of CD43+ pro-B cells. J Immunol 1996; 157: 3804-3811.

16. Mils V, Piette J, Barette C, Veyrune J, Tesniere A, Escot C, Guilhou JJ, and Basset-Seguin N. The proto-oncogene c-fos increases the sensitivity of keratinocytes to apoptosis. Oncogene 1997; 14: 1555-1561.

17. Tsuda T, Hamamori Y, Yamashita T, Fukumoto Y, and Takai Y. Involvement of three intracellular messenger systems, protein kinase $\mathrm{C}$, calcium ion and cyclic AMP, in the regulation of c-fos gene expression in Swiss 3T3 cells. FEBS Lett 1986; 208: 39-420

18. Morgan JI, and Curran T. Calcium as a modulator of the immediate-early gene cascade in neurons. Cell Calcium 1988; 9: 303-311.

19. Cohen DR, and Curran T. The structure and function of the fos protooncogene. Crit rev Oncog 1989; 1: 65-88.

20. Maki A, Berezesky IK, Fargnoli J, Holbrook NJ, and Trump BF. Role of $\left[\mathrm{Ca}^{2+}\right]_{i}$ in induction of c-fos, c-jun and c-myc mRNA in rat PTE after oxidative stress. FASEB J 1992; 6: 919-924.

21. Yamamoto N, Smith MW, Maki A, Berezesky IK, and Trump BF. Role of cytosolic $\mathrm{Ca}^{2+}$ and protein kinases in the induction of the hsp70 gene. Kidney Int 1994; 45: 10931104.

22. Yoshino N, Takizawa M, Akiba H, Okumura H, Tashiro F, Honda M, and Ueno Y. Transient elevation of intracellular calcium ion levels as an early event in T-2 toxin-induced apoptosis in human promyelitic cell line HL-60. Nat Toxins 1996; 4: 234-241. 